\title{
PEMANFAATAN MEDIA PEMBELAJARAN \\ UNTUK MENCIPTAKAN LINGKUNGAN KELAS SD \\ (Alternatif Penciptaan Laboratorium SD yang Efektif )
}

UTILISING THE LEARNING MEDIA

TO BUILD THE CLASS ENVIRONMENT

(Alternative Approach in Developing Effective Elementary School Laboratory)

\author{
Enny Zubaidah \\ Pendidikan Guru Sekolah Dasar Fakultas Ilmu Pendidikan Universitas Negeri Yogyakarta \\ enny_zubaidah@yahoo.com
}

\begin{abstract}
Abstrak
Lingkungan kelas yang bernuansa ke-SD-an saat ini dibutuhkan oleh guru-guru SD, mahasiswa S-1 Pendidikan Guru Sekolah Dasar (PGSD), mahasiswa S-2 Pendidikan Dasar (Dikdas), dan para pengambil kebijakan di bidang ke-SD-an. Itu semua dalam rangka untuk menyesuaikan antara ilmu yang dipelajari dengan dunia yang ada di lingkungan SD. Lingkungan kelas SD idealnya tersedia berbagai sarana sebagai media pembelajaran di SD. Sarana yang berupa media pembelajaran ke-SD-an itu, ditata secara proporsional melalui sudut-sudut mata pelajaran sebagaimana yang ada di SD dan jika mungkin ditambah sudut lain yang menunjang pelaksanaan pembelajaran di SD. Diharapkan melalui lingkungan tersebut, memungkinkan siswa dan guru dapat melaksanakan pembelajaran tentang banyak hal. Hal itu karena di lingkungan kelas tersebut menyediakan berbagai sarana penunjang dan pendukung untuk mempelajari semua mata pelajaran yang ada di kelas SD.
\end{abstract}

Kata kunci: media pembelajaran, matakuliah ke-SD-an, lingkungan kelas SD.

\begin{abstract}
To synchronise the theoretical knowledge taught in college with practical situation existed in elementary schools, all stakeholders of elementary schooling, such as teachers, students, and policy makers, require an environment that closely represents an elementary school-like atmosphere. In this sort of setting, we can find several facilities, as learning media, that are situated proportionally to align with the subjects taught in elementary schools or other perspectives that might be beneficial for supporting the learning process. Having this atmosphere enables students and teachers to gain more lessons during the learning process due to adequate supporting facilities.
\end{abstract}

Key words: learning media, elementary schooling course, elementary school-like environment 


\section{Pendahuluan}

Tahun 1990 dan sebelumnya, masih banyak praktisi pendidikan termasuk para guru di sekolah, khususnya sekolah dasar (SD) dalam melaksanakan tugasnya masih terpaku pada penjelasan secara literal dan masih mengandalkan juklak (petunjuk pelaksanaan) dan juknis (petunjuk teknis) yang diprogramkan oleh pusat/atasannya. Kondisi tersebut, tampak berbeda jika dibandingkan dengan sekarang ini. Perkembangan baru di dunia pendidikan saat itu hingga saat ini yang antara lain ditandai dengan munculnya konsep School Based Management, School Based Competensi, School Based Curriculum, Life Skill, dan sebagainya ini tentunya membawa banyak konsekwensi. Konsekuensi tersebut antara lain adalah semakin besar hak, kewenangan, dan sekaligus kewajiban lembaga pendidikan untuk merencanakan, melaksanakan, dan mengevaluasi program dan berbagai kebijakan dan pemikiran barunya itu.

Kebijakan dan pemikiran konsep tersebut, merupakan upaya untuk meningkatkan mutu pendidikan di berbagai lembaga pendidikan. Di sana-sini upaya untuk meningkatkan mutu Pendidikan Nasional itu sebenarnya telah dilakukan. Bahkan peningkatan itu dari tahun ke tahun itu pun sudah mulai tampak. Akan tetapi, tetaplah harus selalu diupayakan agar mutu pendidikan dasar di negeri ini semakin baik.

Di kota-kota, telah menunjukkan peningkatan mutu pendidikan yang menggembirakan bahkan dapat menunjukkan sebagai lembaga pendidikan yang "mandiri". Di lingkungan kita sudah banyak sekolah-sekolah yang notabene berkelas favourite dan bahkan bertaraf internasional (saat itu). Atas dasar hal tersebut, agar peningkatan dapat merata baik di kota maupun di desa, para praktisi pendidikan hendaknya mampu berusaha untuk dapat mewujudkan peningkatan itu. Salah satunya adalah melalui penciptaan Lingkungan Kelas SD. Penciptaan Lingkungan Kelas SD tersebut sebagai alternatif untuk menciptakan Laboratorium SD yang Efektif. Dengan demikian, SD dapat dikatakan berkualitas baik jika di setiap kelasnya memiliki lingkungan kelas SD yang baik pula. Inilah yang dimaksudkan penulis sebagai upaya menciptakan Laboratorium SD yang Eefektif. Dengan demikian, melalui cara ini secara tidak sengaja para praktisi pendidikan di SD telah berusaha mewujudkan mutu pendidikan SD yang dimaksud.
Peningkatan mutu pendidikan SD melalui penciptakan Lingkungan Kelas SD bukanlah pekerjaan yang mudah, karena semua itu membutuhkan pengetahuan, pemahaman, kemampuan, dan kemauan bagi orang-orang yang terlibat di dalamnya. Di Lingkungan perguruan tinggi penyelengara program studi S-1 PGSD dan S-2 Dikdas, perlu melibatkan dosen dan mahasiswa. Di lingkungan sekolah perlu melibatkan peserta didik, guru, dan komite sekolah, dan bahkan pengawas sekolah. Oleh karena itu, hal ini membutuhkan pemikiran secara bersama-sama demi tercapainya tingkat satuan pendidikan SD yang bermutu.

Untuk tidak menghambat dan memperpanjang usia ketidakberhasilan mutu pendidikan SD di Indonesia, di perguruan tinggi penyelenggara S-1 PGSD dan S-2 Dikdas pun perlu memiliki contoh atau model Lingkungan Kelas SD yang dimaksud. Upaya ini jika terwujud, di samping akan menjadi nilai lebih bagi perguruan tinggi, dapat juga dimanfaatkan oleh sekolah-sekolah SD di sekitar sebagai sumber belajar. Di samping sebagai sumber belajar, dapat juga sebagai model Lingkungan Kelas SD yang baik bagi mereka, sehingga sekolah-sekolah SD akan memiliki kondisi lingkungan kelas yang lebih baik jika dibandingkan seperti kondisi saat ini.

Kenyataan tersebut dapat kita lihat, bahwa kondisi kelas di berbagai sudut SD di sekitar kita belum begitu menggembirakan. Lingkungan kelas SD tampak minus atau gersang akan adanya media pembelajaran. Kelas tampak lengang, tanpa dilengakapi sarana penunjang mata pelajaran secara proporsional. Tidak banyak sarana pendukung mata pelajaran IPA, IPS, bahasa, matematika, PKn, dan lain sebagainya. Belum tampak pula karya peserta didik atau guru yang terpajang di papan pajangan atau tertata dalam kelas melalui sudut-sudut mata pelajaran tertentu. Dengan demikian, peserta didik kurang mendapatkan pengalaman nyata pada mata pelajaran yang harus dipelajari. Kelas hanyalah cukup dilengkapi dengan meja kursi guru, meja kursi peserta didik, almari (kadang-kadang tidak ada), kalender, gambar presiden dan wakil presiden, serta beberapa pajangan lainnya yang kadang-kadang kurang disadari kebermanfaatannya baik oleh guru maupun peserta didik. Kondisi tersebut tampak secara nyata di lingkungan SD sekitar kita. Ini merupakan hasil pengamatan di beberapa SD di Yogyakarta selama penulis mengadakan penelitian dan melaksanakan pengabdian, dan bim- 
bingan Praktik Pengalaman Lapangan (PPL) bagi mahasiswa PGSD. Hal yang lebih memprihatinkan berdasarkan wawancara dengan guru dan pengamatan penulis yang dilakukan saat penulis melakukan kegiatan di SD, justru di beberapa sekolah tidak memanfaatkan KIT IPA sebagaimana mestinya. KIT IPA tersebut sudah cukup lama pengirimannya dari pemerintah, namun masih tersimpan secara rapi di rak almari sekolah karena tidak digunakan. Peta dunia, globe masih terpampang di ruang guru.

Kenyataan tersebut membuktikan, bahwa media pembelajaran yang seharusnya dimanfaatkan oleh guru dan peserta didik untuk melaksanakan proses pembelajaran itu, tidak mewarnai selama proses pembelajaran di dalam kelas. Guru sebenarnya dapat meminta peserta didik untuk memanfaatkan barang-barang bekas untuk dapat dijadikan sebuah karya, terutama pada mata pelajaran SBdP. Melalui bimbingan guru, karya peserta didik pun kadang-kadang menghasilkan karya yang baik untuk dapat dimanfaatkan sebagai sumber belajar. Akan tetapi, hal itu tidak sedikit pula dibiarkan menumpuk begitu saja di ruang guru. Peserta didik juga dapat diminta membawa bungkus odol, bungkus susu bubuk, dan sejenisnya untuk menunjang mata pelajaran matematika. Barang-barang itu selanjutnya diatur bersama guru. Inilah yang antara lain pentingnya pemanfaatan media pembelajaran untuk penciptaan Lingkungan Kelas SD yang efektif. Dengan demikian, tampak bahwa kelas yang kurang dikreasikan oleh sumberdaya yang ada itu akhirnya terwujud. Di beberapa sekolah walaupun sudah menunjukkan lingkungan kelas SD yang mendekati baik, namun di sekolah lain jauh lebih banyak yang tidak memiliki Lingkungan Kelas SD yang baik itu.

Kondisi Lingkungan Kelas SD yang diharapkan ini kiranya dapatlah diciptakan oleh lembaga perguruan tinggi, khususnya penyelenggara S-1 PGSD dan S-2 Dikdas sebagai "model" atau contoh. Penciptaan ini, jika berhasil dapat dimanfaatkan untuk kepentingan perkuliahan di S-1 PGSD dan atau S-2 Dikdas, juga sebagai "contoh" atau "model" bagi sekolah-sekolah SD di sekitar perguruan tinggi, seperti telah diuraikan tersebut. Diharapkan, jika di perguruan tinggi, khususnya penyelenggara S-1 PGSD dan S-2 Dikdas sudah memiliki Lingkungan Kelas SD, tentunya akan merambah ke berbagai daerah lain di sekitarnya.

Upaya ini pula untuk mendukung kompetensi guru dan lulusan perguruan tinggi melalui
Kerangka Kualifikasi Nasional Indonesia (KKNI).

\section{Pembahasan}

Landasan Berpikir Penciptaan Lingkungan Kelas SD

Disebutkan dalam (Kemendikbud 2012) bahwa Standar kurikulum yang ber-KKNI di perguruan tinggi itu tampak bahwa lulusan mahasiswa S-1 berada pada level 6 dan S-2 berada pada level 7 dan 8 . Selanjutnya dirinci bahwa lulusan S-1 pada level 6 tersebut mereka memiliki kualifikasi, (1) mampu mengaplikasikan bidang keahliannya dan memanfaatkan IPTEKS pada bidangnya dalam penyelesaian masalah serta mampu beradaptasi terhadap situasi yang dihadapi, (2) menguasai konsep teoretis bidang pengetahuan tertentu secara umum dan konsep teoretis bagian khusus dalam bidang pengetahuan tersebut secara mendalam, serta mampu memformulasikan penyelesaian masalah prosedural, (3) mampu mengambil keputusan yang tepat berdasarkan analisis informasi dan data, dan mampu memberikan petunjuk dalam memilih berbagai alternatif solusi secara mandiri dan kelompok; Bertanggung jawab pada pekerjaan sendiri dan dapat diberi tanggung jawab atas pencapaian hasil kerja organisasi.

Lulusan S-2 adalah memiliki kualifikasi: (1) mampu merencanakan dan mengelola sumber daya di bawah tanggung jawabnya, dan mengevaluasi secara komprehensif kerjanya dengan memanfaatkan IPTEKS untuk menghasilkan langkah-langkah pengembangan strategis organisasi, (2) mampu memecahkan permasalahan sains, teknologi, dan atau seni di dalam bidang keilmuannya melalui pendekatan monodisipliner, (3) mampu melakukan riset dan mengambil keputusan strategis dengan akuntabilitas dan tanggung jawab penuh atas semua aspek yang berada di bawah tanggung jawab bidang keahliannya, (4) mampu mengembangkan pengetahuan, teknologi, dan atau seni di dalam bidang keilmuannya atau praktek profesionalnya melalui riset, sehingga menghasilkan karya inovatif dan teruji, (5) mampu memecahkan permasalahan sains, teknologi, dan atau seni di dalam bidang keilmuannya melalui pendekatan inter atau multidisipliner, (6) mampu mengelola riset dan pengembangan yang bermanfaat bagi masyarakat dan keilmuan, serta mampu mendapat pengakuan nasional dan internasional (Kemendikbud, 2012). 
Berdasarkan rincian KKNI yang terdapat pada lulusan S-1 dan S-2 tersebut, menggambarkan bahwa salah satu hal yang dapat mendukung kualifikasi tersebut adalah melalui "pemanfaatan media pembelajaran untuk menciptakan Lingkungan Kelas SD yang Efektif". Hal itu cukup beralasan, kalah satunya lulusan hendaklah "menguasai konsep teoretis bidang pengetahuan tertentu secara umum dan konsep teoretis bagian khusus dalam bidang pengetahuan tersebut secara mendalam, serta mampu memformulasikan penyelesaian masalah prosedural". Pernyataan ini terdapat pada level 6, yaitu merupakan salah satu tuntutan pada lulusan S-1.

"Mampu memecahkan permasalahan sains, teknologi, dan atau seni di dalam bidang keilmuannya melalui pendekatan monodisipliner", dan "mampu memecahkan permasalahan sains, teknologi, dan atau seni di dalam bidang keilmuannya melalui pendekatan inter atau multidisipliner". Pernyataan ini terdapat di antara level 7 dan 8 , yaitu merupakan satu di antara level pada lulusan S2.

Hal ini membuktikan bahwa, permasalahan sains, teknologi, dan atau seni di dalam bidang keilmuannya melalui pendekatan monodisipliner", dan "mampu memecahkan permasalahan sains, teknologi, dan atau seni di dalam bidang keilmuannya melalui pendekatan inter atau multidisipliner" seperti diuraikan di atas, merupakan ciri pembelajaran di SD yang tematik-integratif. Itu dapat diwujudkan antara lain melalui penciptaan Lingkungan Kelas SD yang Efektif seperti telah diuraikan tersebut.

Lingkungan kelas SD yang efektif tentulah bernuansa tematik-integratif. Ini dapat disajikan melalui tampilan sudut-sudut matapelajaran di SD. Melalui tampilan itu, Guru lebih mudah dalam membelajarkan kepada peserta didiknya untuk "menguasai konsep baik secara teoretis maupun praktis pada bidang pengetahuan tertentu. Di samping itu, juga mampu memformulasikan penyelesaian masalah secara prosedural". Mengapa dikatakan demikian? Oleh karena, dengan dimilikinya konsep dasar secara teoretis dalam bidang IPA, Pkn, Bahasa, IPS misalnya, guru akan lebih leluasa dan tepat ketika menjelaskan kepada peserta didiknya melalui media yang ada dalam ruang di Lingkungan Kelas SD tersebut secara integrative.
Mahasiswa mempraktikkan dan dapat merasakan bermaknanya/ asyiknya/senangnya belajar dengan lingkungan kelas yang kaya informasi dari sejumlah mata pelajaran di dalam kelasnya. Di samping mahasiswa dapat merasakan pentingnya penciptaan Lingkungan Kelas $\mathrm{SD}$, namun juga mendapatkan ilmu yang nantinya dapat dibawa pulang ke daerahnya untuk mengembangkan Lingkungan Kelas SD yang dimaksud. Dengan demikian, lulusan S-1 PGSD dan lulusan S-2 Dikdas nantinya dapat meningkatkan kualitas pendidikan SD minimum di daerahnya. Untuk menunjang hal itu, di lingkungan lembaga pendidikan tinggi penyelenggara S-1 PGSD dan S-2 Dikdas, dapat mewujudkan Lingkungan Kelas SD tersebut melalui pemanfaatan berbagai media pembelajaran dari matakuliah ke-SD-an, karena dapat dibuat oleh mahasiswa, dan atau melalui pengadaan (membeli) karena mahasiswa tidak dapat membuatnya. Misalnya, media yang berupa alat elektronik dan atau multimedia.

Hakikat, Jenis, dan Fungsi Media Pembelajaran di SD

Media pembelajaran adalah segala sesuatu yang dapat digunakan untuk menyalurkan pesan pada materi pembelajaran, sehingga dapat merangsang perhatian, minat, pikiran dan perasaan peserta didik, dalam kegiatan belajar untuk mencapai tujuan pembelajaran tertentu (Ibrahim dkk, 2000, p.4). Heinich, dkk (1986), juga menyatakan bahwa, dengan memanfaatkan media belajar bagi peserta didik, mereka akan lebih tertarik, bahkan mereka dapat memahami ke arah pembelajaran yang lebih abstrak. Berkaitan dengan pernyataan Heinich, dkk tersebut, menunjukkan bahwa media memiliki peran penting dalam upaya memahamkan konsep pada materi pembelajaran yang sedang dipelajari. Tanpa memanfaatkan media tujuan pembelajaran tidak dapat dicapai secara maksimal. Berkaitan dengan hal tersebut, Edger Dale, (Sardiman, 2014, p.8) telah menyusun pola pengalaman belajar yang disebut dengan "kerucut pengalaman". Berdasarkan konsep Edger Dale tersebut, tampak bahwa peserta didik akan mendapatkan pengetahuan yang banyak jika guru membelajarkan konsep itu secara langsung pada objek yang sedang dipelajari. Sebaliknya, peserta didik akan mendapat mengetahuan sedikit karena guru dalam membelajarkan hanya melalui ceramah. Hal itu tampak pada gambar 1 berikut ini. 

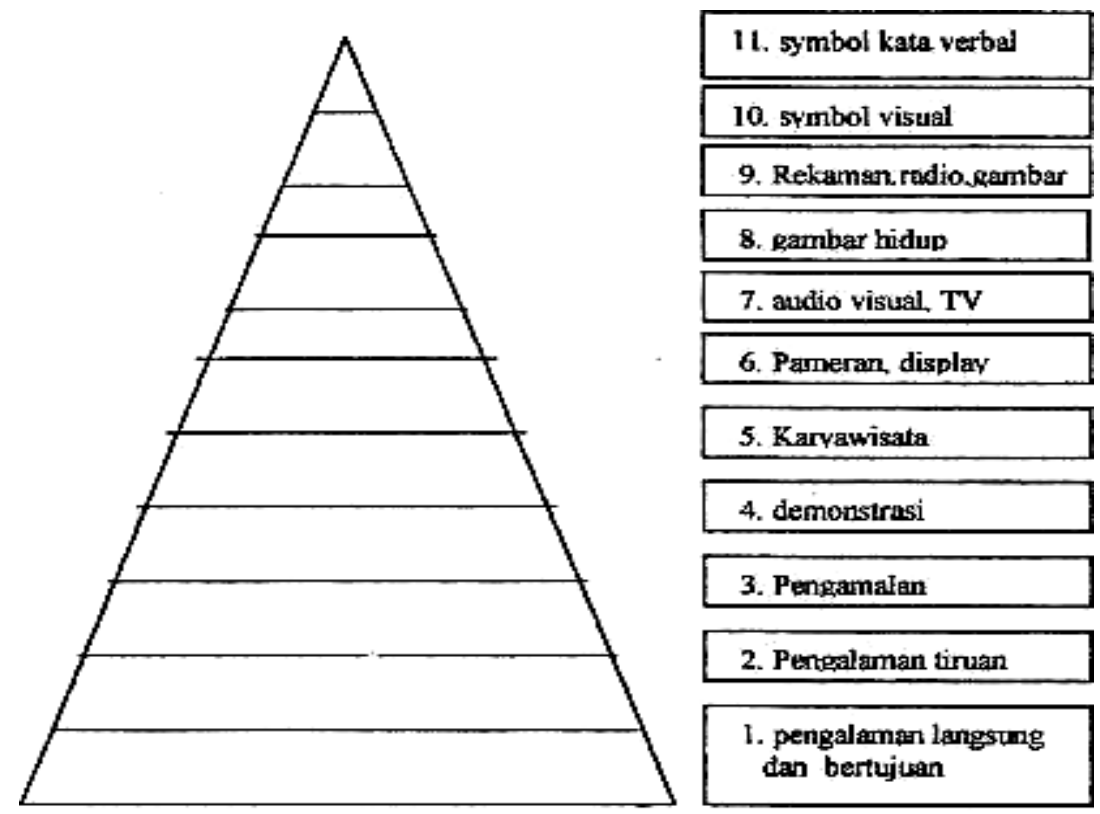

Gambar 1. Kerucut Pengalaman Edger Dale

Berdasarkan gambar 1 tersebut, menunjukkan bahwa penguasaan materi pelajaran dapat dikuasai mulai dari pengalaman langsung dan pengalaman tidak langsung. Masalah yang dipelajari jika digunakan objek secara langsung, maka dengan mudah peserta didik dalam menguasainya. Sebaliknya, dalam mempelajari sesuatu jika hanya digunakan penjelasan melalui symbol verbal, maka penguasaan dari objek yang dipelajari tersebut semakin sedikit, dan mungkin bahkan mudah terlupakan.

Pengalaman langsung yang dilakukan melalui mengamatan dengan menggunakan benda konkret, merupakan ciri cara belajar peserta didik di SD. Peserta didik SD, menurut Piaget berada pada tahap perkembangan usia operasional konkret. Pada tahapan tersebut, yakni antara usia 06/07-11/12 tahun, mereka dalam belajar atau berpikir masih mendasarkan pada objek yang konkret (Berk, 2006, p.247). Selanjutnya dinyatakan bahwa pada tahapan perkembangan tersebut, anak belajar melalui pengindraan terhadap benda-benda konkret (perceptual learning), atau dapat juga melalui benda-benda tiruan. Dengan demikian, pada masa ini peserta didik SD dalam belajar hendaklah menggunakan objek langsung yang berupa media pembelajaran.

Untuk mempermudah pemahaman kita tentang media pembelajaran, terdapat beberapa jenis media dan pengelompokannya. Setiap ahli media, dalam mengelompokkan jenis media pembelajaran tidak selalu sama. Sardiman, dkk (2002, pp.28-82) mengelompokan menjadi tiga, yaitu: (i) media grafis, yang meliputi: gambar/ foto, sketsa, diagram, bagan/chart, grafik, kartun, poster, peta/globe, papan flanel, dan papan buletin, (ii) media audio. Media ini meliputi: radio, alat perekam pita magnetik, laboratorium bahasa, dan (iii) media proyeksi diam, yang meliputi: film bingkai, film rangkai, media tranparansi, media tak tembus pandang, film, televisi, video, dan permainan dan simulasi.

Saat ini media pembelajaran dapat mencakup banyak hal. Masalah itu mengingat adanya pengetahuan dan teknologi yang berkembang dengan pesat saat ini. Hal itu memungkinkan adanya media komputer dan atau internet, yang sangat dibutuhkan. Akan tetapi, kadangkadang justru tidak tersedia di beberapa sekolah. Sardiman (2014, p.83) di buku barunya juga memaparkan bahwa media pembelajaran dikelompokkan menjdi dua macam, yaitu: media by utilization dan media by design.

Media by utilization adalah media yang secara tidak sengaja dirancang untuk media pembelajaran, namun bisa dipakai untuk mencapai kompetensi atau tujuan pembelajaran. Selanjutnya dikatakan Sardiman bahwa, dalam media by utilization tersebut, media yang ada di pasaran yang disesuaikan dengan materi pelajaran yang akan diajarkan dapat dimanfaatkan untuk mencapai tujuan pembelajaran.

Media by design adalah media yang sengaja dirancang oleh guru (dan atau dosen tentunya) dengan memanfaatkan barang-barang yang ada atau yang tersedia di lingkungan. Hal ini di samping dapat memenuhi kebutuhan dalam kegiatan pembelajaran, juga untuk 
mengembangkan kreativitas yang tinggi dan jiwa inovatif daru guru/dosen.

Menurut Abdorrakhman (2010, p.141), terdapat empat macam media pembelajaran, yaitu: media visual, media audio, media audiovisual, dan multimedia. Media visual, adalah media non elektronik yang hanya dapat dilihat, yakni meliputi: papan tulis, white board, flannel board, flip chard, poster model atau solid aid. Media audio, adalah media yang hanya dapat didengar, contohnya: amplifier, radia, taperecorder, SD player. Gitar dan gamelan. Media audiovisual, adalah media yang dapat didengar dan dilihat. Misalnya: slide proyektor, televise, film strip proyector, video plater, dan DVD player, computer. Multimedia, adalah media yang menampilkan materi pembelajaran dengan segala keunggulannya, yakni menampilkan berbagai teknik penyajian dengan memanfaatkan teknologi computer dan $L C D$ projector sebagai alat utamanya.

Berdasarkan jenis rincian media pembelajaran yang telah dipaparkan tersebut, para praktisi pendidikan khususnya di bidang ke-SDan diharapkan tertantang untuk mengetahui "apa dan bagaimana" media pembelajaran tersebut dapat dimanfaatkan bagi kepentingan pembelajaran, baik di lingkungan perguruan tinggi penyelenggara S-1 PGSD dan S-2 Dikdas maupun di SD.

Untuk memiliki penguasaan pembelajaran yang baik, bagi peserta didik/mahasiswa; guru/dosen, media pembelajaranlah satu-satunya yang utama untuk dipenuhi. Melalui pemenuhan kebutuhan tersebut, pemahaman peserta didik/mahasiswa terhadap materi pembelajaran/ matakuliah lebih dapat dikuasai. Dengan demikian, memanfaatkan media pembelajaran yang sesuai dengan kebutuhan peserta didik/mahasiswa diperlukan.

Depdiknas (2003, pp.1-4) menyarankan bahwa dalam pembelajaran perlunya digunakan Pendekatan Kontekstual (Contextual Teanching and Leaming) (CTL). Pendekatan tersebut lebih menekankan bahwa "dalam belajar, peserta didik diajak belajar melalui pengalamannya sendiri secara alamiah, kemudian mereka mengkonstruksi pengetahuannya, lalu memberi makna pada pengetahuan itu. Peserta didik harus tahu makna belajar dan menggunakan pengetahuan dan keterampilan yang diperolehnya itu untuk memecahkan masalah dalam kehidupannya. Untuk itu, tugas guru/dosen adalah mengatur srtategi belajar, membantu menghubung- kan pengetahuan lama dan baru, serta memfasilitasi peserta didik dalam belajar".

Pendekatan CTL adalah merupakan bentuk kegiatan yang mengaitkan antara materi yang diajarkan dengan situasi dunia nyata peserta didik/mahasiswa, dan hal ini dapat mendorong peserta didik membuat hubungan antara pengetahuan yang dimilikinya, kemudian mengaitkan dengan pengetahuan barunya dan menerapkannya dalam kehidupan mereka seharihari. Cara tersebut dapat dilakukan dengan melibatkan tujuh komponen utama pembelajaran yang efektif melalui pendekatan CTL. Ketujuh hal yang dimaksud adalah konstruktivisme (Constructivism), bertanya (Questioning), menemukan (lnquiry), masyarakat belajar (Learning Comunity), pemodelan, (Modeling), dan penilaian sebenarnya (Autentic Assessment) (Depdiknas, 2003, p.5). Hal itu tampaknya sejalan dengan pembelajaran yang dilakukan berdasarkan pada Kurikulum Tingkat Satuan Pendidikan (KTSP) dan Kurikulum 20013 melalui pendekatan Saintifik (Sciencetific Approach).

Pendekatan saintifik adalah pendekatan yang dalam proses pembelajarannya peserta didik diajak untuk berperan secara aktif dalam pembelajarannya. Hal tersebut akan mudah dilakukan oleh guru/dosen dan peserta didik/ mahasiswa jika di tempat mereka belajar, tersedia lingkungan kelas efektif, yaitu lingkungan kelas yang menyediakan berbagai perlengkapan media pembelajaran. Kelas tersebut mendukung terciptanya pembelajaran yang efektif, karena sarana kelas dapat digunakan sebagai sumber untuk: (1) memunculkan kegiatan untuk melakukan pengamatan/percobaan, (2) memunculkan pertanyaan karena adanya sumber permasalahan yang mendukung terciptanya proses pembelajaran dalam kegiatan percobaan tersebut, (3) memunculkan penalaran dari hasil percobaan tersebut, dan (4) memunculkan ide berdasarkan penalaran tersebut untuk mengomunikasikan kepada orang lain, (Kemendikbud, 2013). Hal itu tentulah perlu dukungan untuk menciptakan suasana dan kondisi, melalui penampilan lingkungan kelas SD yang kondusif. Penciptaan Lingkungan Kelas SD yang seperti itu tentulah diperlukan tatanan secara proporsional melalui sudut-sudut mata pelajaran yang ada di SD.

\section{Lingkungan Kelas SD yang Ditawarkan}

Di Indonesia, kelas SD sebagian memiliki kelas dengan ukuran yang tidak telalu luas. Ukuran tersebut berkisar antara 7x6m atau 8x6 
m. Dengan ukuran kelas sebesar itu, menurut hemat penulis Lingkungan Kelas masih memungkinkan untuk diperluas lagi. Untuk itu, kerja sama yang baik terutama antara perguruan tinggi penyelenggara PGSD dan Dikdas, Dinas Pendidikan, dan komite sekolah sangat dibutuhkan.

Kelas SD di Indonesia terbagi menjadi enam tingkatan, yakni mulai kelas I sampai dengan kelas VI. Untuk pengaturan Lingkungan Kelas SD yang akan dibuat, tentunya bergantung pada berbagai pertimbangan: (a) ruangan cukup leluasa, dengan ukuran paling tidak $8 \times 10-14 \mathrm{~m}$. Isi ruangan memiliki sudut-sudut seperti halnya yang terdapat pada mata pelajaran di SD. Terdapat sudut matematika, sudut IPA, sudut IPS, sudut PKn, sudut bahasa, namun juga dilengkapi dengan berbagai sarana pendukung dalam pelaksanaan pembelajaran di $\mathrm{SD}$; (b) lingkungan kelas dilengkapi dengan sejumlah media pembelajaran elektronik, seperti televisi, layar monitor, computer/laptap, proyektor, alat musik, dan perlengkapan lainnya jika mungkin. (c) Lingkungan kelas SD yang efektif dapat menampilkan konsep pembelajaran melalui tampilan yang menyenangkan dan bermakna. Di samping terdapat sudut membaca yang beralaskan karpet dan sejenisnya, juga dilengkapi kursi pendek untuk guru. Di sekitarnya juga dilengkapi dengan rak-rak berisi buku penunjang mata pelajaran di kelas itu dan buku cerita anak. (d) Lingkungan Kelas SD hendaklah bersih dan rapi. Sandal dan sepatu tidak dibawa masuk. Seperti halnya ruangan para dokter, yang ber-AC, yang kadang-kadang mereka memakai sandal khusus dalam ruangan. Di samping itu, ruangan dilengkapi meja-kursi guru, meja dan kursi peserta didik yang fleksibel dan dapat dilipat saat tidak diperlukan, papan tulis tidak permanen yang dapat disesuaikan kebutuhan, tempat memajang karya peserta didik, tempat memajang media pembelajaran, tempat memajang kotak-kotak yang disusun secara rapi untuk menyimpan karya peserta didik sebagai portofolio mereka, westafel disertai serbet, serta sejumlah media lain yang mendukung pelaksanaan pembelajaran di kelas itu.

Jadi lingkungan kelas SD yang dimaksud hendaklah meliputi banyak hal. Lingkungan kelas ini tentulah bukan harga mati, yang berarti perlu disesuaikan dengan situasi, kondisi dan kebutuhan dari kelas yang ada. Oleh karena itu, jika diperlukan rak untuk pengaturan buku, maka terdapat sudut perpustakaan kecil di kelas itu. Jika diperlukan bulettin board/papan pajang karya peserta didik, perlu papan pajang itu disediakan. Jika diperlukan papan tulis, tentu perlu disediakan, serta kebutuhan lain jika diperlukan

Lingkungan Kelas SD yang dilengkapi dengan berbagai tampilan media pembelajaran, jika akan digunakan untuk kepentingan sebagai "model" tentunya cukuplah satu kelas saja, karena memungkinkan kelas itu di samping dapat dimanfaatkan untuk pembelajaran tematikintegratif, juga dapat difungsikan sebagai kunjungan. Jika kelas difungsikan sebagai kelas tematik-integratif, walaupun ditata berdasarkan sudut-sudut mata pelajaran, dan dilengkapi dengan sudut membaca dan sudut music, misalnya, namun diharapkan tetap mudah jika dilakukan perpindahan.

Misalnya: dengan tema Indahnya kebersamaan di kelas IV, dengan materi cerita Malin Kundang. Cerita itu disajikan pada peserta didik melalui video yang dapat dilihat dan didengar. Tampilan dalam video tersebut memungkinkan peserta didik untuk mempelajari IPA tentang hukum Archimedes. Diajaklah para peserta didik untuk berpindah ke sudut IPA. Di sudut itu terdapat media yang dapat memperjelas pemahaman mereka tentang bukti hukum Archimedes tersebut. Di sana terdapat baskom besar yang diisi air dan dilengkapi dengan kapalkapalan. Ketika guru akan menjelaskan asal daerah cerita Malin Kundang dan budaya di daerah tersebut, diajaklah mereka ke sudut IPS. Di sudut IPS itu terdapat daerah yang memperjelas memahaman peserta didik tentang asal dan budaya daerah dari cerita tersebut. Ketika guru akan meminta peserta didik untuk menceritakan kembali cerita Malin Kundang, dengan memperhatikan struktur bahasa dan ejaan yang benar, diajaklah mereka ke sudut bahasa. Di situlah guru dapat memperjelas cara menulis cerita dengan struktur bahasa dan penggunaan ejaan yang benar. Ketika guru akan membelajarkan tentang konsep perkalian/pembagian berdasarkan gajinya Malin Kundang, diajaklah mereka ke sudut matematika. Itulah gambaran sepintas tentang perlunya Lingkungan Kelas SD melalui sudut-sudut mata pelajaran di SD. Oleh karena itu perlu pengaturan yang baik agar kelas tidak dikatakan sebagai gudang.

Salah satu alternatif pengaturan lingkungan kelas yang dapat mendukung terciptanya Lingkungan Kelas SD ini, lebih diarahkan pada bentuk pengaturan yang sederhana seperti yang dikemukakan Olilla (1992). Menurutnya 
"Lingkungan kelas SD yang efektif" hendaklah diatur dengan bentuk sudut-sudut sesuai dengan mata pelajaran yang dipelajari di kelas itu". Hal ini jika di negara barat mengkondisikan kelasnya melalui sudut science, sudut musik, sudut computer, sudut listening, speaking, reading, dan writing, dan sebagainya, maka di Indonesia dapat kita ciptakan menjadi lingkungan kelas yang memiliki sudut-sudut sesuai mata pelajaran di SD, seperti diuraikan di atas.

Berdasarkan paparan tersebut, dapat disimpullkan bahwa, lingkungan kelas hendaklah, (1) cukup luas, tempat pembelajaran peserta didik bisa dalam posisi duduk santai di karpet dan atau duduk di kursi jika diperlukan, (2) guru dapat dengan mudah mengambil media sebagai sumber belajar yang lainnya dengan cepat dan mudah, (4) peserta didik lebih leluasa bergerak, (5) menyingkat tempat dan waktu saat pembelajaran berlangsung, (6) pembelajaran dapat berlangsung tematik-integratif.

Dalam Suwito (tth) disarankan, bahwa pengaturan kelas SD dapatlah dimanfaatkan sebagai tempat pendidikan dan pengajaran, yang penyusunannya memanfaatkan banyak hal. (1) papan tulis/papan tayang, (2) informasi dinding, (3) papan tempel, (4) rak yang disertai tempat menyimpan alat peraga yang transparan, (5) meja science, dan (6) rak perpustakaan. Pengaturan tersebut, hendaklah lebih memperhatikan pengelompokan setiap mata pelajaran, sehingga seolah-olah kelas tampak diatur berdasarkan kelompok mata pelajaran. Pemanfaatan benda-benda tersebut dijelaskan berikut ini.

\section{Papan Tulis}

Pemanfaatan papan tulis yang baik, adalah jika papan tersebut digunakan secara efektif untuk kepentingan praktis. Papan tulis juga sekaligus dapat dimanfaatkan sebagai papan tayang. Saat ini seperti yang biasa kita tayangkan dalam kelas melalui media layar dengan bantuan LCD untuk menyajikan tayangan materi dari laptap/computer. Untuk itu, papan tersebut hendaklah disiapkan di depan kelas dengan tampilan yang luas dan leluasa agar peserta didik dapat melihat/membaca informasi melalui layar tersebut secara leluasa pula. Papan tayang dapat juga berbentuk kecil. Hal ini dapat digunakan guru untuk memperjelas pemahaman peserta didik ketika guru menjelaskan sesuatu melalui media berbentuk bik-book atau kalender. Situasi seperti ini, biasanya peserta didik duduk di karpet/tikar dan guru sesekali menjelaskan atau duduk di kursi pendeknya. Jadi, papan tayang di depannya hendaklah dilengkapi karpet sebagai tempat duduk peserta didik ketika mereka sedang menyimak cerita atau menyimak penjelasan tentang materi dari guru.

\section{Informasi Dinding}

Dinding, bukan hanya difungsikan sebagai tempat untuk menempelkan kalender, pajangan huruf-huruf, tata-tertib, slogan, rumus-rumus dan hafalan-hafalan lainnya, namun dinding dinding juga dapat difungsikan sebagai sumber informasi untuk kepentingan kelas. Untuk itu dinding perlu dilengkapi papan yang berbingkai yang berfungsi sebagai bulettin board/papan pajang.

Bulettin board atau papan pajang adalah sarana pembelajaran yang fungsinya sebagai media pembelajaran. Papan ini sebaiknya dipasang memanjang di dinding bagian belakang, dengan ketinggian yang masih dalam jangkauan peserta didik. Papan ini difungsikan sebagai sarana untuk menempelkan karya peserta didik pada mata pelajaran apa saja, yaitu tempat untuk memajang karya-karya/hasil tugas-tugas yang diberikan guru kepada peserta didik. Semua karya tersebut ditempel secara teratur dan sistematis, oleh siswa bersama-sama guru. Misalnya karya berupa gambar, cerita/karangan, kliping, puisi, laporan singkat dari kelompok, komik, dan beberapa jenis karya peserta didik lainnya yang dapat ditempel di dinding. Jika sudah ada karya baru yang akan ditempelkan lagi, karya lama disimpan dalam kumpulan karya milik masing-masing peserta didik di dalam kotak khusus/stopmap khusus milik masingmasing peserta didik sebagai portofolio. Jadi, dalam proses pengaturan ini sebaiknya peserta didik dilibatkan, baik dalam menempatkan karya yang akan ditempelkan, teknik menyusun karya yang akan ditempelkan, jenis karya yang akan ditempelkan, teknik menempelkan, maupun pengaturan lainnya perlu arahan guru.

\section{Plastik Transparan/Kotak Bening sebagai Tempat Penyimpanan Alat Peraga}

Plastik transparan ini dapat berbentuk gelas, yang dapat difungsikan untuk menempatkan benda-benda yang dibawa ke dalam kelas oleh peserta didik sesuai dengan matapelajaran yang dipelajari. Misalnya dalam pelajaran IPA, dapat berupa jenis-jenis batuan, biji-bijian, bunga-bungaan, jenis daun yang sudah dikeringkan, dan lain sebagainya. Pada pelajaran Matematika, dapat berupa beberapa jenis bangun, pada mata pelajaran bahasa, dapat berupa 
kartu-kartu baik kartu huruf, suku kata, kata, maupun kartu kalimat. Pada pelajaran SBdP), gelas dapat digunakan untuk menyimpan beberapa jenis peralatan jahit-menjahit. Misalnya beberapa jenis jarun, benang, benik, dan sebagainya. Contoh benda-benda tersebut, hendaklah dikumpulkan dan diatur oleh peserta didik bersama guru sehingga setiap saat dapat dilihat dan diperbincangkan dan dipergunakan oleh mereka. Benda yang disimpan dalam plastik transparan atau kotak transparan tersebut, dikelompokkan pada sudut-sudut mata pelajaran tertentu.

\section{Meja Science}

Meja ini difungsikan sebagai tempat untuk meletakkan berbagai informasi. Misalnya pada mata pelajaran IPA, dapat berupa (1) beberapa tanaman yang ditanam dalam pot sebagai percobaan, (2) akuarium, (3) tetarium (tempat binatang melata, (4) insektarium (tempat serangga) dan penghuninya, serta hal-hal lain yang menarik bagi peserta didik. Bendabenda lain yang dapat diletakkan di sana ialah magnet, potongan besi, kuningan, kayu, karet, balon, jenis-jenis batuan, biji logam, dan sebagainya. Pada pelajaran IPS misalnya berupa peta yang dapat memuat banyak informasi. Misalnya masalah ibu kota propinsi, sungai, gunung, pakaian adat, rumah adat, rambu-rambu lalu lintas, tempat ibadah, dan sebagainya. Demikian juga pada mata pelajaran yang lain. Semua itu hendaklah disesuaikan dengan kelompok-kelompok bidang studi yang telah diatur sebelumnya. Melalui informasi tersebut dapat membangkitkan rasa cinta peserta didik pada alam, budaya, bahasa serta kesadarannya akan kekuasaan Alloh Tuhan Yang Maha Kuasa. Di samping itu, dapat menciptakan rasa persatuan, kesatuan berbangsa serta dapat menciptakan rasa sayang kepada tanah air, antar kawan, dan terhadap makhluk hidup lainnya. Benda-benda tersebut dapat mendidik rasa tanggung jawab bersama dan memberikan pengetahuan serta pemahaman terhadap peserta didik lain tentang fakta dan masih banyak hal yang perlu diketahui oleh mereka.

\section{Perpustakaan}

Perpustakaan ini terutama untuk kepentingan peserta didik dalam kelas, yang menyimpan bermacam-macam judul dan jenis buku. Buku tersebut tentulah yang menunjang mata pelajaran, termasuk buku cerita yang wajib dibaca anak. Perpustakaan kecil ini seperti telah diuraikan di atas, dapat diatur di sudut membaca. Ketika guru menjelaskan atau ketika bercerita, buku itu diambil dari perpustakaan kecil atau dalam rak di sudut membaca tersebut. Kegiatan dan kebiasaan guru terhadap penyajian materi yang dibaca dan disimak peserta didik di sudut itu, secara tidak langsung perpustakaan kecil ini dapat menumbuhkan rasa cinta pada buku, yang akhirnya untuk memupuk minat baca peserta didik. Kecintaan peserta didik terhadap buku bacaan pada akhirnya mampu mengembangkan minat baca pada mereka.

Perpustakaan, di samping mengoleksi buku pelajaran juga perlu dilengkapi buku dongeng. Buku lain dapat berupa buku pelajaran, kamus, insiklopedi, majalah, koran, kliping, foto, dan sebagainya. Pengaturan koleksi perpustakaaan kecil ini sebaiknya menampilkan sebagian atau seluruh sampul luar buku agar dapat menarik minat baca para peserta didik terhadap buku yang dimiliki di kelas itu.

Gambar 2, 3, 4, 5, 6, 7, 8, 9, dan 10 di bawah ini merupakan lingkungan kelas SD yang dimaksud.

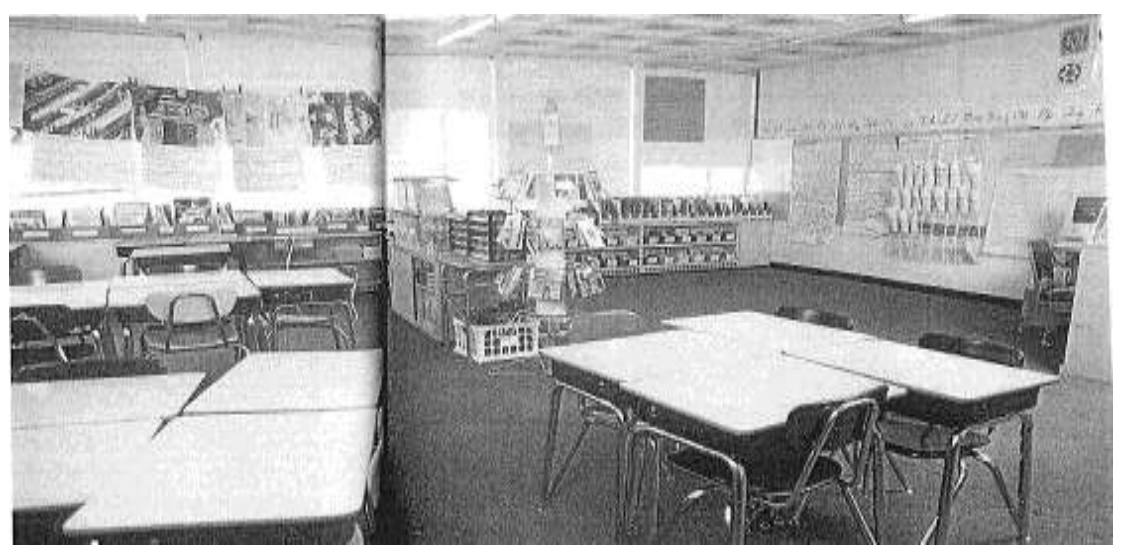

Gambar 2. Lingkungan Kelas SD (Fountas \& Pinnel, 2001, pp.viii-ix) 


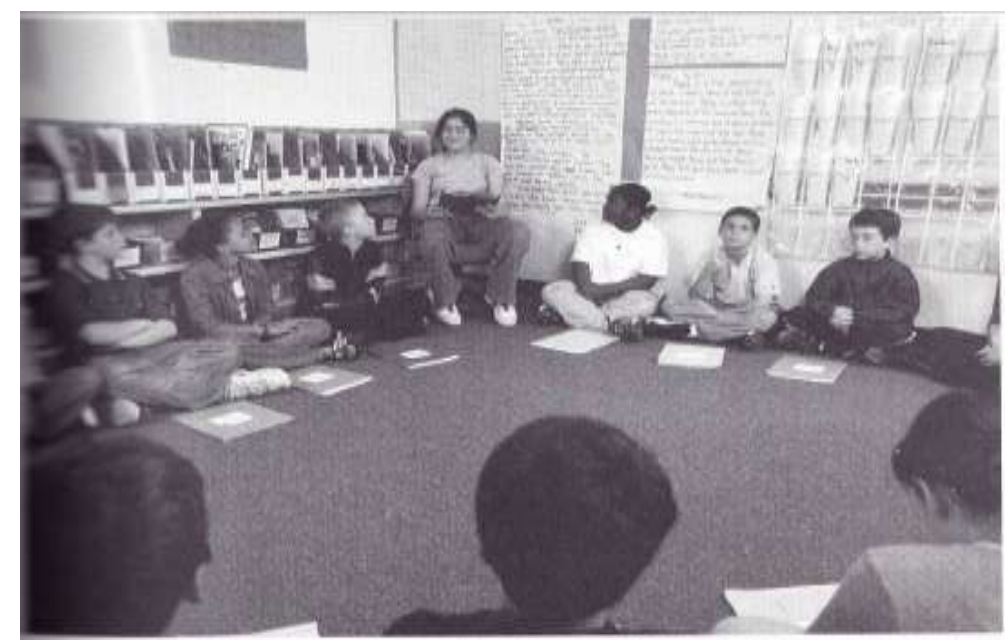

Gambar 3. Peserta didik duduk di karpet sambil menyimak cerita dari guru (Fountas \& Pinnel, 2001, p.xv)

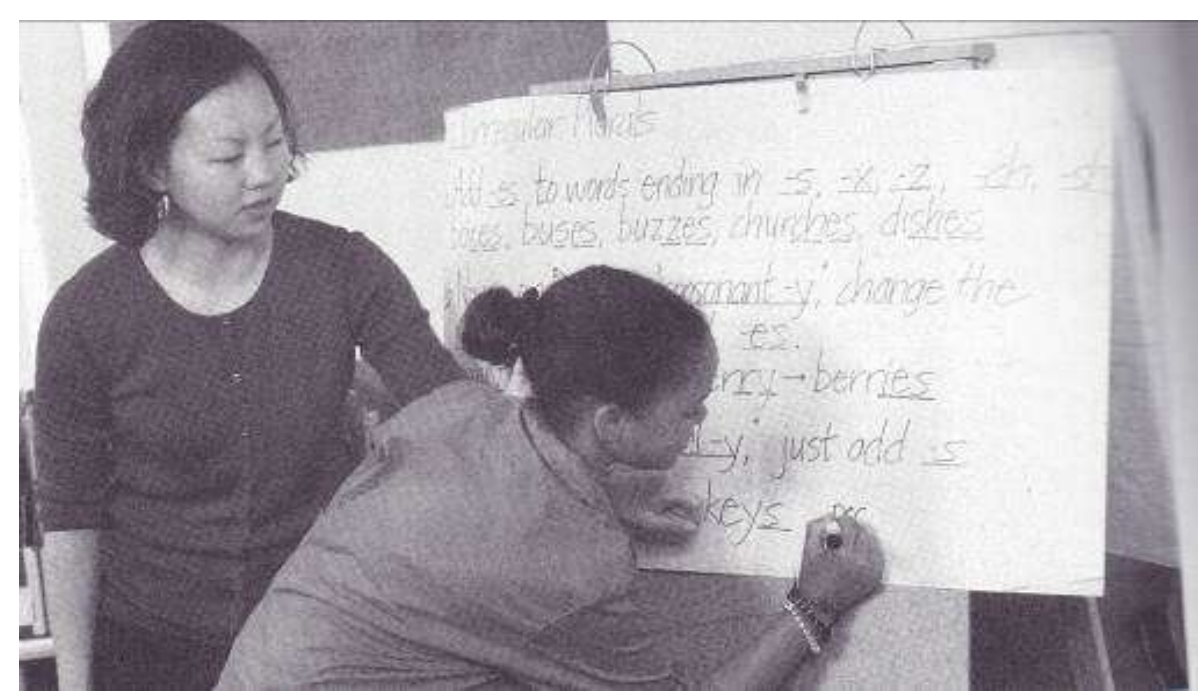

Gambar 4.Salah satu peserta didik sedang menulis di papan tulis kecil dengan bimbingan guru, (Fountas \& Pinnel, 2001, p.xviii)

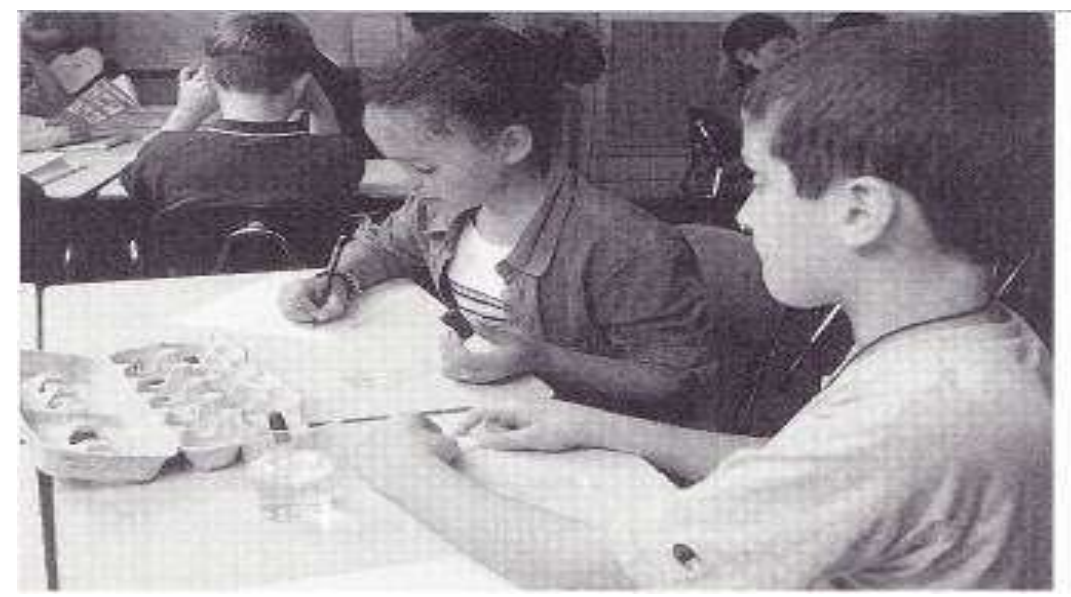

Gambar 5. Peserta didik mencatat hasil kerja kelompok setelah melakukan percobaan (Fountas \& Pinnel, 2001, p.xxi ) 

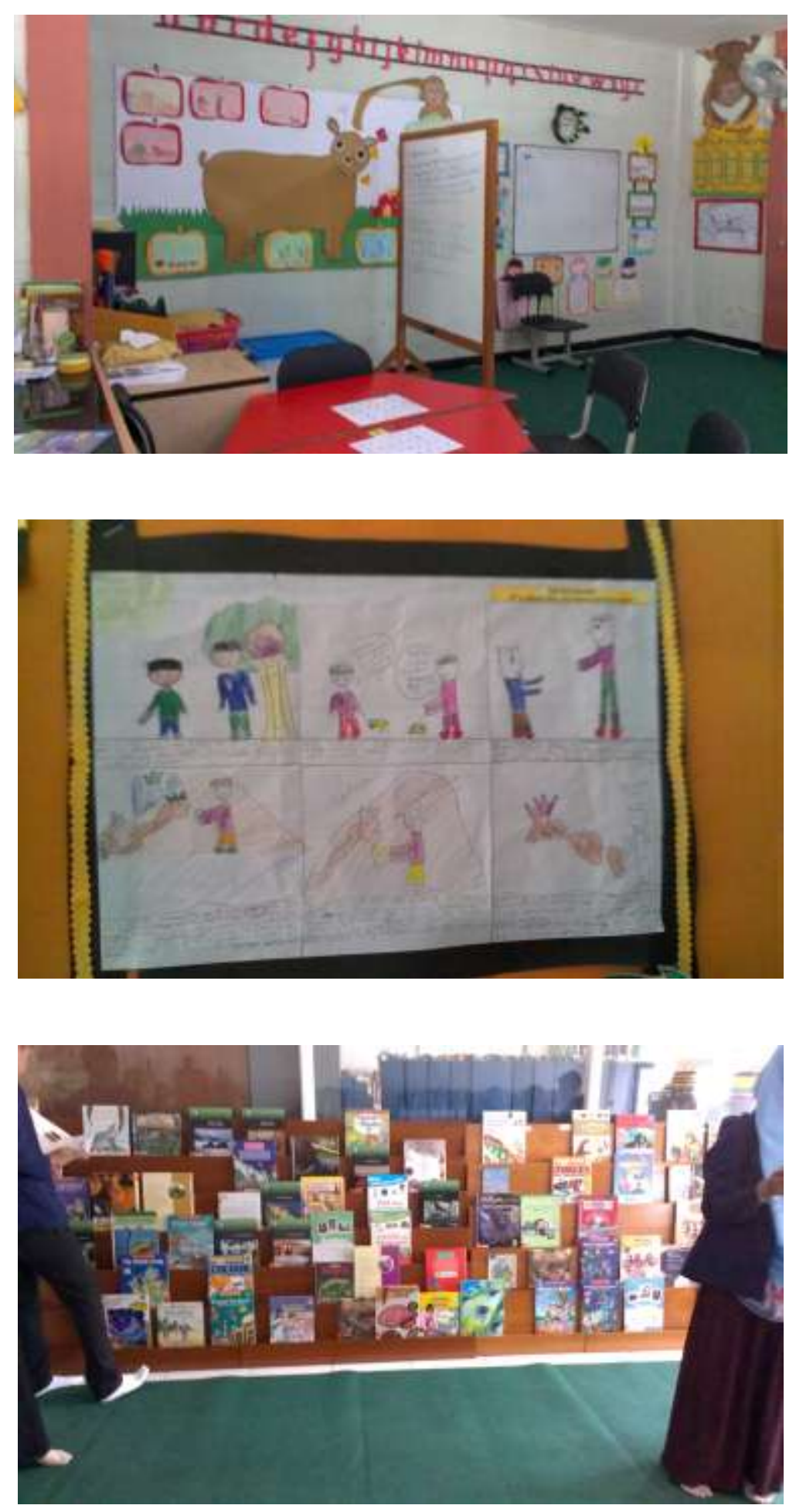

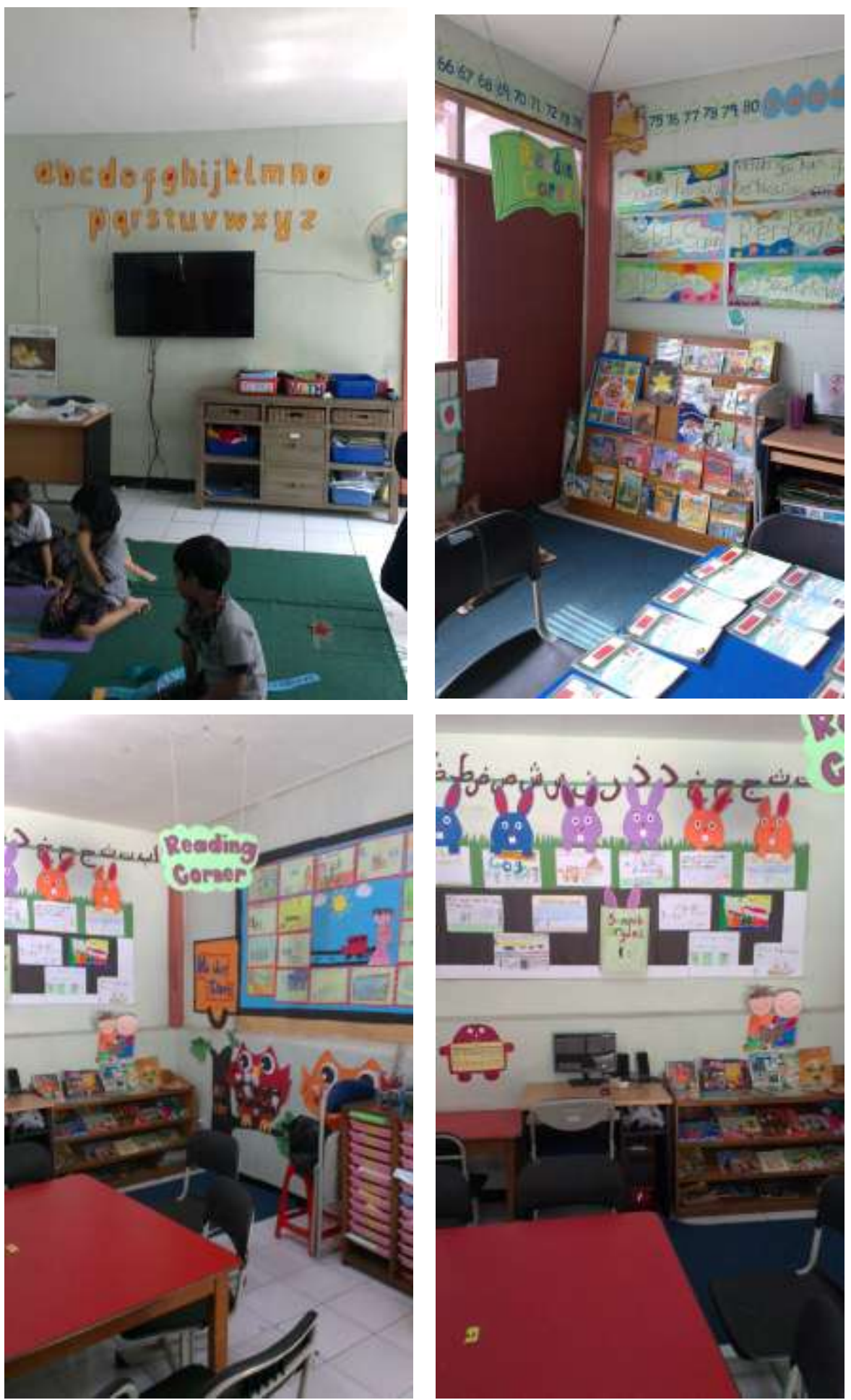


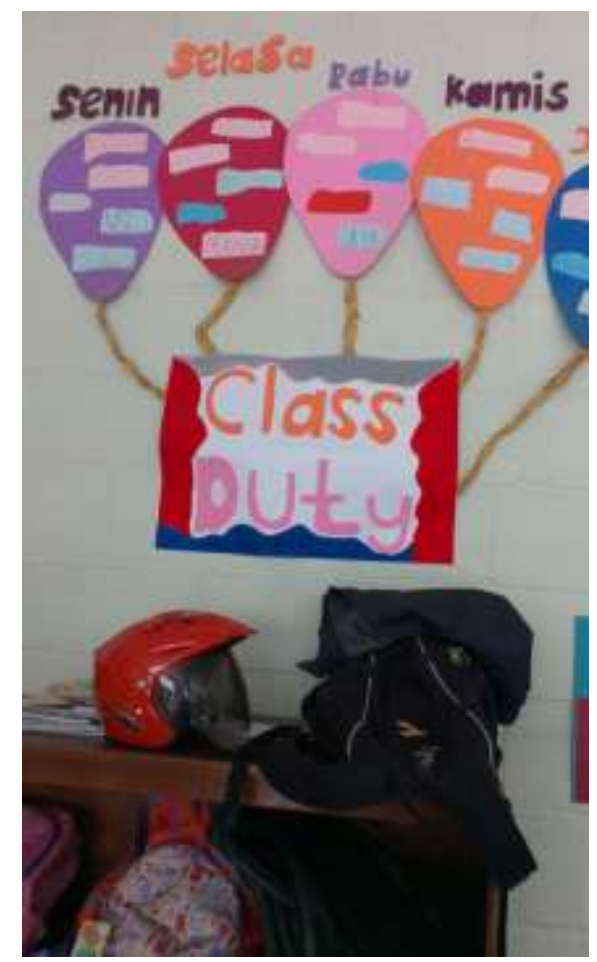

Berdasarkan atas uraian dan gambargambar tersebut, pengaturan Lingkungan Kelas SD tersebut tampak berdasarkan atas kepentingan pada masing-masing kelas, yakni dengan memperhatikan tampilan sudut-sudut yang menunjang setiap mata pelajaran. Dengan demikian, Lingkungan kelas SD yang Efektif adalah lingkungan yang dapat berupa kumpulan bahan penunjang mata pelajaran yang berfungsi sebagai media pembelajaran (Olilla, 1992).

Memanfaatkan media pembelajaran dan diatur berdasarkan sudut-sudut mata pelajaran yang dipelajari di kelas itu, berarti guru sekaligus menciptakan Lingkungan kelas untuk kepentingan kelasnya sendiri. Dengan memanfaatkan media pembelajaran, di samping menanamkan nilai pendidikan juga menanamkan nilai pembelajaran.

Pada bagian awal sudah diuraikan bahwa, pengaturan lingkungan kelas yang efektif hendaknya diatur melalui sudut-sudut bidang mata pelajaran, Oleh karena itu, untuk kepentingan ini pengaturan disarankan sesuai dengan kebutuhan pada setiap kelas dan isi pada setiap mata pelajaran. Di samping itu, peserta didik perlu dilibatkan baik dalam mengusahakan karya yang akan dibuat, teknik membuat, dan teknik pengaturan selanjutnya. Hal tersebut mengingat bahwa Lingkungan Kelas SD yang akan diciptakan tersebut, akan menjadi bagian dari mereka. Mereka yang menentukan, mereka mem- buat, mereka pula yang mengatur, dan diharapkan mereka merasa memilikinya. Demikian juga penciptaan lingkungan kelas SD di S-1 PGSD dan S-2 Dikdas. Mahasiswa pun harus mempunyai peran aktif baik dalam penentuan karya yang akan dibuat, teknik membuat, dan teknik pengaturannya.

Model lingkungan kelas SD di perguruan tinggi adalah lingkungan kelas yang dapat dimanfaatkan baik oleh peserta didik SD, guruguru SD, mahasiswa S-1 PGSD, S-2 Dikdas maupun dosen PGSD/Dikdas. Upaya ini hendaklah didukung adanya kerja sama yang baik dan komitmen yang baik pula antara sesama dosen, mahasiswa, dan pengelola perguruan tinggi. Untuk itu, antar dosen pengampu mata kuliah, pimpinan fakultas, pengambil kebijakan di universitas, serta para mahasiswa, yang keseluruhannya di lingkungan PGSD dan Dikdas perlulah memiliki satu bahasa, yaitu "sedang menciptakan Lingkungan Kelas SD yang efektif". Pada akhimya perguruan tinggi diharapkan mampu mencipta, mewujudkan, mengelola, dan yang pada akhirnya memiliki "Model Lingkungan Kelas SD" dengan memanfaatkan Media Pembelajaran yang sengaja dirancang, dibuat, diatur, dan dikelola bersama oleh anggota masyarakat S-1 PGSD dan S-2 Dikdas. Dengan kerja sama yang baik, diharapkan akan memberikan manfaat yang baik pula, baik bagi guru dan peserta didik; dosen dan mahasiswa; 
dan penyelenggara S-1 PGSD dan S-2 Dikdas di perguruan tinggi dan bahkan di perguruan tinggi lainnya.

Manfaat yang diperoleh oleh guru-guru yang sudah mengajar, mereka selain dapat mengembangkan kreativitas berpikir peserta didiknya melalui pemanfaatan media pembelajaran untuk penciptaan Lingkungan Kelasnya yang efektif, juga dapat menerapkan metode pembelajaran secara kontekstual. Peserta didik, mendapatkan pengalaman nyata dan langsung selama mengikuti pembelajaran. Mereka tidak hanya sekedar membayangkan saja, namun mereka yang merasakan sendiri, karena mereka mampu menghayati, memahami, memaknai, mempraktikan sendiri dan melakukannya sendiri. Dengan demikian, peserta didik mendapatkan pengalaman yang berharga dan mereka memperoleh pengetahuan, pengalaman, pemahaman, yang berguna dalam kehidupannya secara nyata.

Bagi dosen, dapat dengan mudah untuk mengembangkan metode pembelajaran melalui pengalaman nyata, dalam mengajarkan mata kuliahnya. Untuk menunjang penguasaan teknik mengajar di SD dan sekaligus menguasai materi $\mathrm{SD}$, mahasiswa juga dapat menguasai materi pada matakuliahnya dengan baik. Dosen juga dapat meminta mahasiswanya untuk melakukan micro-teaching di lingkungan kelas SD untuk berpraktik langsung mengajar temannya sendiri.

Jadi, Lingkungan kelas yang efektif merupakan interaksi latar yang dikreasikan bersama antara siswa, guru, kepala sekolah, dan orang lain yang terlibat dalam lingkungan kelas dan di luar kelas (Glazer and Searfoss, 1988). Demikian juga penciptaan Lingkungan Kelas SD yang baik di lingkungan perguruan tinggi tinggi, berarti penciptaan Lingkungan Kelas yang melibatkan seluruh anggota masyarakat perguruan tinggi. Menurut Lindon (dalam Glazer and Brown, 1993, p.11) kelas merupakan tempat yang menyediakan kondisi fisik, sosial, emosional yang memungkinkan peserta didik dan guru berinteraksi untuk tujuan nyata, bertukar bahasa untuk menciptakan komunitas pembelajaran sehingga peserta didik bukan saja memiliki penguasaan mata pelajaran saja, namun juga berkembang bahasanya. Ini berarti bahwa untuk terampil mengomunikasikan mate-ri pelajaran yang telah dipelajari melalui pen-dekatan saintifik itu, peserta didik mampu menyampaikannya. Oleh karena itu, media pembelajaran hendaknya diciptakan dalam lingkungan kelas dengan baik agar dapat memper- mudah bagi guru/dosen dalam melihat perkembangan pemahaman peserta didiknya/mahasiswanya selama proses pembelajaran.

Dari pengertian tersebut, diharapkan dengan memanfaatkan media yang terorganisir dalam kelas secara baik, antara guru/peserta didik dan antara dosen/mahasiswa dapat melaksanakan proses pembelajaran lebih baik pula, lebih hidup dan lebih bermakna, sehingga tujuan pembelajaran dapat dicapai.

\section{Penutup}

Pemanfaatan Lingkungan Kelas SD yang efektif memungkinkan peserta didik dapat belajar apa saja di kelasnya, karena lingkungan kelas efektif menyediakan berbagai sarana penunjang dan pendukung semua mata pelajaran yang ada di kelas yang bersangkutan. Melalui keaktifan dan kekreatifan guru bersama dengan peserta didiknya dan atau dosen bersama mahasiswanya diharapkan pembelajaran akan lebih hidup dan bermakna, sehingga tujuan pembelajaran dapat dicapai. Lingkungan Kelas SD tersebut, hendaklah mampu memberikan nuansa ke-SD-an melalui penyajian sarana belajar yang berupa media pembelajaran yang ditata secara proporsional melalui sudut-sudut mata pelajaran yang ada di SD dan di kelas itu.

Mulai sekarang kita sebagai pembelajar dan pengajar hendaklah berani mencoba tampil beda dibandingkan sebelumnya dalam penciptaan Lingkungan Kelas SD yang dimaksud. Kelas perlunya diwujudkan, diatur, dikelola, dan ditampilkan bersama peserta didik/mahasiswa di dalam kelas, yang ditampilkan melalui sudutsudut mata pelajaran yang dipelajari di kelas itu. Hal ini dapat dilakukan dengan cara mengajak peserta didik/mahasiswa untuk membuat bersama-sama pada kajian mata pelajaran/matakuliah tertentu. Guru/dosen tidak harus menunggu perintah saat akan berkreasi, namun melalui tindakan yang terpuji tentulah disetujui. Guru/dosen tidak harus menunggu bahan setelah disediakan bahan, namun dapat memanfaatkan lingkungan yang ada untuk membuat bersama-sama dengan peserta didik/mahasiswa, dan memanfaatkan media yang ada di sekolah, sehingga dapat mendukung terciptanya Lingkungan Kelas SD yang dapat difungsikan sebagai alternatif Penciptaan Laboratorium SD yang Eefektif. 


\section{Daftar Pustaka}

Abdorrakhman, G. (2010). Esensi praktis belajar dan pembelajaran. Bandung: Humaniora.

Berk, L. E. (2006). Child develompment. Boston: Illinois State Univercity.

Depdiknas. (2003). Pendekatan kontekstual. (Contextual Teaching and Leaming (CTL). Jakarta: Departemen Pndidikan Nasional. Dirjen Dikdasmen. Direktorat Pendidikan Lanjutan Pertama.

Depdiknas. (2003). Kurikulum 2006. Kurikulum berbasis kompetensi sekolah dasar. Jakarta: Depdiknas.

Fountas, I.C. \& Pinnel, G.S. (2001). Guiding Readers and Writers Grades 3-6. Portsmouth: Heinemann.

Glazer, S M \& Brown, C. S. (1993). Portofolios and beyond: Collaborative assesment in reading and writing. Norwood: Christopher Gordon Publishers.

Glazer, S. M \& Searfoss, L. W. (1988). Reading diagnosis and instruktion: $a C$ A-L-M Aproach. Englewood Cfffs, New Jersey: Prentice Hall.
Heinich, R; Molanden, M. \& James, R D. (1986). Instructional media. New York: Macmillan Publishing Company.

Ibrahim, Sihkabundden; Suprijanto; Kustiawan, Usep. (2000). Media Pembelajaran, bahan sajian akta mengajar. Jakarta: Depdiknas. Universitas Negeri Malang. Fakultas llmu Pendidikan.

Kemendikbud. (2012). Kerangka kualifikasi nasional Indonesia. Jakarta: Dirjen Dikti Kemendikbud.

Kemendikbud. (2013). Materi pelatihan guru implementasi kurikulum 2013. Jakarta: Kemendikbud.

Olilla, L.C \& Margie I Mayfield. (1992). Emerging literacy. Preschool, Kindergarten, and Primary Grades. Boston: Allyn and Bacon.

Sardiman, A.S, dkk. (2014). Media pendidikan. Jakarta: Rajawali Press.

Suwito, Umar. (Tanpa tahun). Lingkungan kelas sebagai sumber belajar. Yogyakarta: Fakultas llmu Pendidikan. 